\title{
Food waste in the United States: A contributing factor toward environmental instability
}

\author{
Michael E. Hickey and Gulnihal Ozbay* \\ The Department of Agriculture and Natural Resources, College of Agriculture and Related Sciences, Delaware State University, Dover, DE, USA
}

\section{Edited by:}

Mohiuddin Md. Taimur Khan,

Washington State University, USA

Reviewed by:

Devendra P. Saroj, University of

Surrey, UK

M. A. Karim, Southern Polytechnic

State University, USA

*Correspondence:

Gulnihal Ozbay, The Department of

Agriculture and Natural Resources,

College of Agriculture and Related

Sciences, Delaware State

University, 1200 North DuPont

Highway, Dover, DE, USA

e-mail: gozbay@desu.edu
The world's population continues to increase at record rates along with corresponding nutritional needs and related agricultural consequences. In the United States, food waste levels serve as dominant components of land-fill masses, oil and freshwater waste, methane and $\mathrm{CO}_{2}$ emissions, damage to wildlife ecosystems, and substantial financial losses. Agricultural effects on the environment were investigated through various research studies, referenced in this document, and efforts made toward food waste recycling were discussed as noteworthy models concerning improvements in sustainable agricultural practices. Food waste levels in the United States can be traced as faults of consumers, agricultural businesses, as well as federal legislation and there is an evident need for reform to maintain consumer health, viable foreign affairs, and environmental sustainability. Present agricultural practices are intense and rapid, increasing the risk of soil infertility and commercial alterations in production yields; repercussions well documented in neighboring nations. Experts argue that food waste in developed countries damages food availability around the world and, based on current agricultural practices and production, there is debate concerning the earth's sustainability of the human population in coming generations. This article delineates the extent to which food waste in the United States serves as an integral factor toward environmental instability on a global scale with emphasis on the critical capacity of public reception of the content discussed herein.

Keywords: food waste, environment, unsustainability, environmental instability, the United States' food waste, food demand

\section{INTRODUCTION}

\section{FOOD LOSSES IN THE UNITED STATES}

Most of the population growth is expected to continue in underdeveloped countries with limited technologies and venues (the Food and Agricultural Organization of the United Nations, 2009). The demand for food and water must be met as the human population is expected to rise to nine billion people by the year 2050. With current food consumption and trends, this means we must increase overall food production by over $70 \%$ (the Food and Agricultural Organization of the United Nations, 2009). This increase cannot be sustained and food prices cannot be afforded.

Recent research by the Food and Agricultural Organization (Food and Agricultural Organization of the United Nations, 2013) of the United Nations concluded that the United States consume the most calories per person (2012) and are the second most obese nation (2013) in the world and, according to Buzby and Hyman (2012), account for nearly $\$ 166$ billion in wasted food each year. In particular, meats, poultry, and fish account for the highest food loss yields in the United States, followed by fruits/vegetables and dairy products; 41,17 , and $14 \%$ of net losses, respectively (Buzby and Hyman, 2012). Warner (2013) concluded that as much as $70 \%$ of the average American diet consists of commercially processed foods, as opposed to the perishable goods that account for $72 \%$ of the food wasted in the United States (Buzby and Hyman, 2012). Boxstael et al. (2014) found that more than half of supermarket consumers prefer processed foods when grocery shopping due to their trust in the highly extended shelf-life expiration date shown on the product packaged label. Clarity and trust regarding expiration dates appears to have a significant impact on consumer selection and, as such, a need for shelf-life extension in perishable goods is necessary to improve consumer dieting habits/safety, food loss yields, and environmental sustainability (Mensitieri et al., 2011).

According to the United States Census Bureau (2014), America is comprised of the third largest national population in the world with over $98 \%$ of its citizens originating from families native to countries outside of the continent. As such, the United States maintains a larger assortment in daily dieting habits and meal varieties than any other nation with an average of 50,000 different food products available for purchase at the typical American grocery store (Kantor et al., 1997). It has been estimated that as much as $25 \%$ of the world's food is lost post-harvest due to microbial spoilage while as much as $40 \%$ of America's food is wasted due to inefficient production and careless consumer habits; not accounting for foods lost due to diseased livestock (Nellemann, 2009; Gunders, 2012) (Figure 1A).

As described by Botkin and Keller (2011), the world's population has more than doubled in the past four decades and the risk of sustainability-loss concerning earth's resources, relative to population, is at an all times high. Problems in food losses are 


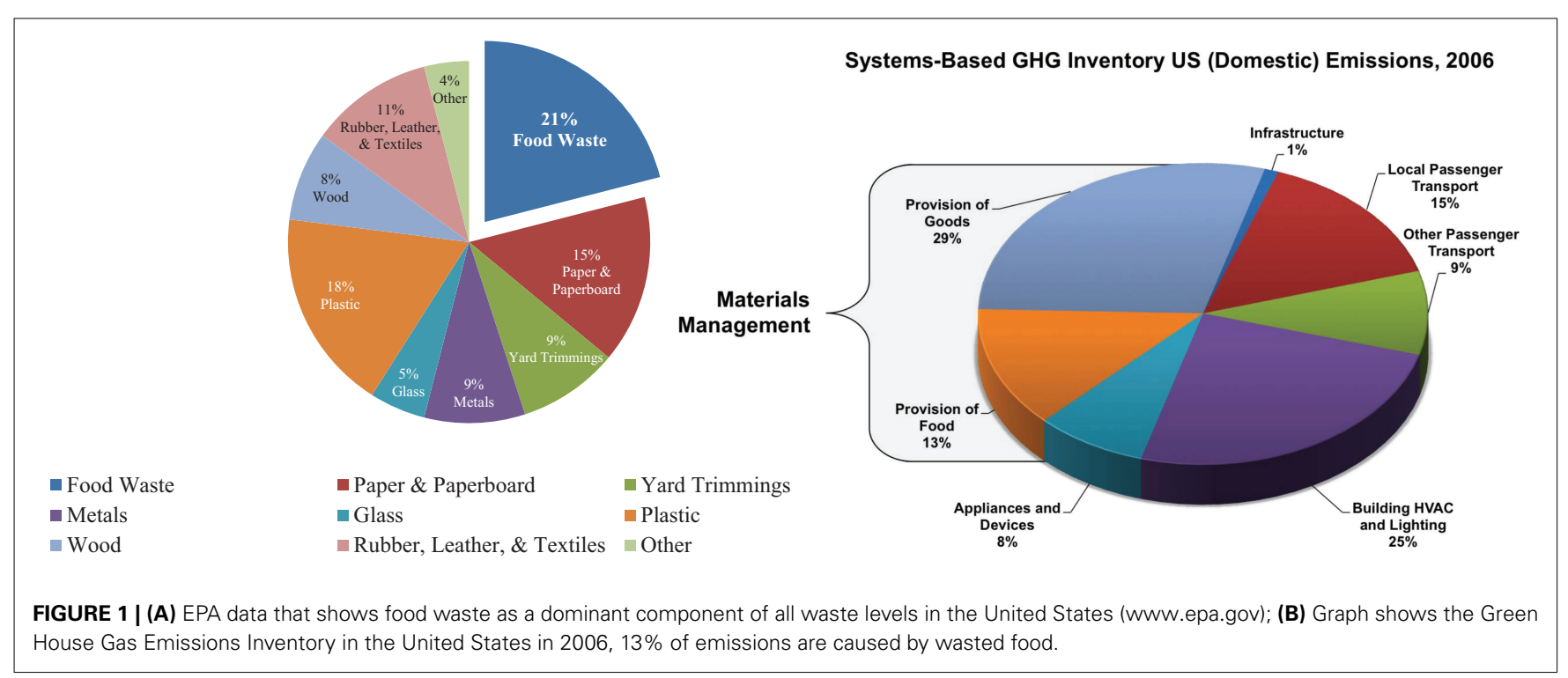

seen at the commercial, consumer, as well as food service levels and, in addition to environmentally-related issues, result in direct financial consequences as the costs to properly manage such waste continues to increase over time (Payne-Palacio and Theis, 2011). With a number of major famines impacting regions such as East/West Africa, North Korea, Vietnam, Russia, and China within the last century alone, there is a very real risk that the United States are equally as susceptible to mass food shortages due to economic recession, ties to international warfare, or even global climate change (Weber and Stern, 2011). Furthermore, effort toward resource sustainability concerning foods in the United States must be increased and awareness of such possibilities needs to be expressed at a public level to present meaningful change and promote long-term public safety.

\section{ENVIRONMENTAL FACTORS CONCERNING FOOD WASTE}

It is estimated that more than one-fourth of the freshwater used each year in the United States is lost in the irrigating of crops that are never consumed; a 50\% increase in only three decades (Hall et al., 2009). In addition, Hall and his associates (2009) concluded that approximately 300 million barrels of oil are wasted each year, due to such food losses, in transporting perishable goods for consumer distribution which accounts for nearly $4 \%$ of the United States' annual oil consumption. It is apparent that the mismanagement of perishable goods in the United States acts as a strong contributing factor toward economic instability, consumer health, and environmental change. According to the United States Environmental Protection Agency (EPA), food waste accounts for at least $17 \%$ of the nation's land-fill masses and has exceeded $\$ 1.3$ billion in waste management expenses, to date (Schwab, 2010; Buzby et al., 2011). Additionally, freshwater- and fossil fueluse increase considerably relative to food waste levels and result in excess carbondioxide $\left(\mathrm{CO}_{2}\right)$ and $\left(\mathrm{CH}_{4}\right)$ methane emissions from decomposing foods (Hall et al., 2009). Buzby et al. (2011) explained that the decomposition of food waste in United States landfills contributes to as much as $34 \%$ of all human-related methane emissions in the world; a chemical emission that is 21 times more powerful than $\mathrm{CO}_{2}$ in contribution to global warming. In addition to its chemical emissions, food waste acts as a medium for microbiological growth that greatly increase the risk of pathogenic vector (i.e., Mosquito) transfer. Collectively, food waste levels directly influence the health of municipal waste workers, most notably via inhalation of resulting toxins, and are of major concern in landfill-exposure associated congenital malformation effects (Giusti, 2009). Stuart (2009) discussed the idea that more food wasted in developed countries increases the demand to replenish goods in those countries which, in turn, depletes the availability of foods in underdeveloped regions of lesser economic magnitude to the industry. Even small change by United States consumers would result in mass increases in food availability around the world as even a $15 \%$ decrease in food waste would be enough to feed at least 25 million people (Food and Agricultural Organization of the United Nations, 2012).

Corresponding with such trends in modern agriculture, issues concerning sediment and air pollution, damage to wildlife and aquatic ecosystems, and soil losses have been concluded as resulting effects of agricultural practices (Reimer and Prokopy, 2014). In addition, recent research by Datta (2014) argued that the majority of innovative, cutting-edge agricultural practices in developed countries are focused solely on rapid crop growth and food production that is proven damaging to the long-term fertility of the respective soil being used; suggesting that large United States agricultural businesses will be forced to relocate to eastern countries in a matter of decades. Similarly, Kagabo et al. (2013) report substantial decreases in agricultural production in Rwanda due to intensive farming practices that left slope-lands infertile in a short time. The scientific notion that soil fertility is impermanent sufficiently describes the significance of the issue at hand, concerning the value of food wasted in the United States and its effects on surrounding nations.

\section{RESOURCEFUL EFFORTS TO RECYCLE AND REDUCE FOOD WASTE}

Second only to paper-based products, foods are one of the largest components of municipal waste in the United States, while only 
$3 \%$ is utilized for recycling purposes. When taking into account the effect of methane emissions from land-fill impacted food, the process of composting for use as a fertilizer appears to be a novel trend in resourcefully managing food waste (Saer et al., 2013; Sundberg et al., 2013). Yan et al. (2011) found that composting of food waste can be specialized in the synthesis of various products, such as ethanol, by use of specific enzyme applications and research in the area is gaining global popularity. Furthermore, trends in food waste composting have been proven as promising alternatives to destructive agricultural pesticides and the practice is required by federal law in Japan (Takata et al., 2012). Relative to advancements in food waste recycling, research is being conducted to develop a sink-intact garbage disposal system that purifies and recycles water from food waste for dishwasher use (Hanson, 2011). Additionally, in attempt to rely less on motor oil, major steps are being taken optimize cooking oil-waste as a primary component in bio-fuel. Kalam et al. (2011) described the use of palm and coconut oil-waste as novel foundations for bio-diesel blends in automobile use, concluding that food-based oils contribute significant reduction in emissions as alternative motor vehicle fuels. The Environmental Protection Agency (2014) has developed a Food Recovery Challenge to which any business or organization is encouraged to participate voluntarily to improve food waste levels, support the community, diminish landfill masses, reduce greenhouse gasses, and be recognized for participation on a national scale; all data being monitored by the EPA. In any case, resourceful efforts in food waste recycling are premature and needs for increased efficiency in use of such renewable resources are essential to maintain environmental sustainability in the United States.

In contrast to combating the results of food waste, many researchers have focused their efforts toward evading the cause. As much as one-fourth of total food losses are caused by microbial growth and degradation that render food products unsuitable for human consumption (Nellemann, 2009; Gustavsson et al., 2011). While careless consumer habits, such as discarding daily-leftover dinner scraps, cannot be regulated or maintained through legislative control, natural inhibition remedies of microbial growth and activity on foods remains a plausible vector of interest toward extending perishable shelf-life as well as consumer health. Furthermore, recent efforts in environmentally friendly packaging of perishable goods have shown promising involvement in shelf-life extension and research in modified-atmospheric packaging is frequently applied toward commercial sales (Macé et al., 2012; Alfaro and Hernandez, 2013). There remains, however, vast room for improvement in food waste control and management as waste levels will inevitably increase with the human population that is expected to reach 9 billion by the year 2050 (Botkin and Keller, 2011) (Figure 1B).

\section{FEDERAL INFLUENCE ON AGRICULTURALLY-RELATED ENVIRONMENTAL ISSUES}

According to Iowa Senator Charles Grassley, the recently enacted Agricultural Act (2014), valued at $\$ 956$ billion in citizen tax payments, offers as little as $10 \%$ of farmers in the United States as much as $70 \%$ of federal benefits that are not available to the remaining $90 \%$, suppressing small or medium farm growth due to disadvantages in federal relations; the few benefactors described are the wealthiest farmers in the nation. Senator Grassley (2014) further discussed the notion that loop-holes exist in current agricultural legislation that allow over-funneling of government funds to agricultural managers that are not legally deserving and promote corruption in the industry as well as tax increases to the general population. Mardsen and Morley (2014) share consistent views in their argument that privatized versus public innovations in food production will serve as strong contributors to food crises world-wide. Furthermore, there is evidence that privatized food industries have access to advanced technologies, commercial processes, and federal benefits to which public sector companies are denied; resulting in stronger reliance and power contributed to larger food corporations that are in majority control of certain agricultural commodities (Deibel, 2013). There is apparent disorder in agricultural legislation that must be addressed further as the cost of such entropy is not limited to financial consequence but to the sustainability of earth's resources for generations to come. The fate of the United States lies heavily in the hands of the federal government and, as such, legislative officials hold responsibility to positively impact the environment through reasonable agricultural practices and related ethics in commercial sales.

Relative to legislative regulations, the International Organization for Standardization (ISO)—-the world's largest independent organization for the voluntary development of international standards - has served a critical role in the advancement and configuration of international standards concerning food production of plant and animal origins (Becchetti and Neri, 2013; Arvanitoyannis et al., 2014). Though manufacturers are not required by law to follow the framework, ISO has implemented ISO 14040: Life Cycle Assessment (LCA) which offers food production companies international standards for use toward maintaining records of the environmental impacts that are exhibited as a result of the life cycle of a given product before, during, and after processing (Arvanitoyannis et al., 2014). Such innovations in regulatory concepts establish integral vectors of data compilation that provide and enhance foreknowledge of causal environmental consequences related to every stage of food production. Though recently confirmed and revised for validity (Finkbeiner et al., 2006), some experts argue that ISO 14040 is vulnerable to inconsistent interpretation which leads to inapplicable variables, invalid trends related to product demand, inconsistent data overall, and is ultimately more financially costly than productive (Weidema, 2014). Arvanitoyannis et al. (2014) supported this notion by explaining that the lack of public databases containing comprehensive levels of ISO 14040 data actually hinders interdisciplinary interactions in the industry which force LCA studies to focus on one aspect of agricultural production over others of equal importance to the processes involved (Koroneos et al., 2005). Weidema (2014) explained that such a lack in consistency of the interpretation of LCA reduces the probability of ISO 14040 implementation on a global scale. In any case, ISO 14040: Life Cycle Assessment (LCA) appears to hold the legitimate potential to manipulate the present food developmental processes toward a universally transparent and environmentally sustainable industry. If enhanced to a consistently accessible and interdisciplinary-recognized source for the 
monitoring of all environmental consequences associated with each stage of food processing and production, LCA could potentially serve as the foundation for a new framework of agricultural legislation in the United States. Furthermore, food companies with LCA data that conclusively support the environmental benefits of their respective food production processes will have access to substantial marketing advantages over competitors which, if not explored properly by the federal government, could drive agricultural commerce out of the United States due to environmentally active agricultural conglomerates overseas.

\section{DISCUSSION}

American diets continue to stray from perishable foods as meal choices are increasingly dominated by convenience and ease of preparation (van der Horst et al., 2010; Warner, 2013). As a result, United States' consumers progressively waste costly, perishable goods and promote excessive agricultural commerce that contributes to food shortages in underdeveloped regions, as well as over-use and abuse of earth's soil (Stuart, 2009). Considering that nearly three-fourths of food waste is composed of perishable items, while $70 \%$ of the American diet consists of commercially processed foods, there is strong evidence that irresponsibility in shopping habits acts as a major gateway to food waste in the United States (Buzby and Hyman, 2012; Warner, 2013). Although it would be ideal for American citizens to collectively strive for environmentally friendly food practices, that is not the case and, as with any issue concerning the mass population, the most prominent course of valid change must begin at the source. Food companies must adopt the obligation to safely extend the shelflife of their products in order to minimize food waste levels and to increase food availability around the world. By offering extended shelf-life to perishable food products, an increase in likelihood that the food items are consumed will be exhibited. Most notably, Kuswandi et al. (2012) developed a colorimetric packaging label using a specialized nanofiber-based film that can easily distinguish spoilage levels on a given food product via label color change. If such technologies were universally adopted or required by law, an essential trust in perishable purchases would be exhibited by consumers, food items would remain in storage rather than wrongfully discarded, and zip-lock bags or plastic saran-wrap would serve as increasingly essential accessories of consumer food managements in the home setting. Because the major concern of modern corporations is largely financial, incentive must be offered to encourage such commercial transformations by either compensation, efforts in research, or federal legislation.

Consistent with conclusions made by Yan et al. (2011), that food composting can be specialized for purpose by specific enzymatic presence, it seems that waste management practices could serve as the most viable gateway toward diminishing food waste effects on the environment. Just as recycling practices have been in high promotion within the last few decades, with distinct blue waste-bins for example, specialized waste containers or aerosol sprays can be distributed that contain natural enzymatic cocktails favoring environmentally friendly decomposition of food waste; significantly decreasing methane and $\mathrm{CO}_{2}$ emissions, land fill masses, as well as waste management expenses nationwide. In any case, statistics concerning food waste and its negative effects on global climate change represent the need for mass alterations in waste management practices and many public sector waste management companies are studying methods that allow the capturing of methane emissions for recycled use as heat energy (Themelis and Ulloa, 2007).

To understand the impact of food waste on environmental sustainability in its entirety, comprehension of agricultural pollution is essential. Kersebaum et al. (2003) found that as much as $55 \%$ of all non-point water pollution is caused by agricultural runoff to neighboring channels (Environmental Protection Agency, 2012). Although not directly consumed by humans, these polluted water sources are essential to wildlife ecosystems and the negative health effects of such wildlife intoxications are, in the highest probability, unnoticed by the human majority. Volk et al. (2009) explained that intensive-farming, seen heavily in developed nations, requires over-application of nitrogen and phosphorus to ensure crop yields that result in their excessive accumulations in non-point water sources (Buckley and Carney, 2013). In addition, various aquaculture practices require antibiotic applications that can be hazardous among consumption as well as contribute to the decimation of certain target species as a result of agricultural malpractice. According to Cabello (2006), high concentrations of prophylactic antibiotics, that are applied to maintain health in aquacultures, result in the development of antibiotic-resistant bacteria in the gut flora of its consumer. Furthermore, it is suggested that such antibiotic concentrated tanks eventually find drainage to the environment where similar feats are exhibited (Cabello, 2006). In general, agricultural practices are essential to modern society and are wholly positive in their functional processes; however, it is agriculture in excess that acts as an environmentally diminishing practice. If higher levels of wasted food require higher levels of agricultural production to replenish vacancy on grocery store shelves, while higher levels of agricultural production contribute to environmental instability, increasing levels of food waste act as a major influence of consequences related to excessive agricultural production (Figure 2).

In correlation to major increases in human populations over the past few decades, urbanized land in the United States has increased by at least $57 \%$ since 1982 and over 4050 square meter of farm land is lost every minute due to the mass urbanization of America (American Farmland Trust, 2007). Notably, urbanization of farmland increases the demand for food availability as human populations rise and viable soil diminishes. As a result, farmland must be maintained in areas of availability which ultimately results in destruction of wildlife ecosystems. For example, as much as $73 \%$ of New Zealand's forests have been destroyed for such uses and as little as 3\% of native North American prairies still exist today due to destruction for use as farmland (NZB, 2013; WAF, 2013). It is apparent that increased food waste in the United States has damaging effects on consumers worldwide and, as the human population increases, it is reasonable to articulate that wildlife ecosystems will ultimately pay the price of such agricultural carelessness. Short of forcing all Americans to live in apartment style housing, democratic legislation will prevail allowing humans to maintain possession of rights to land 


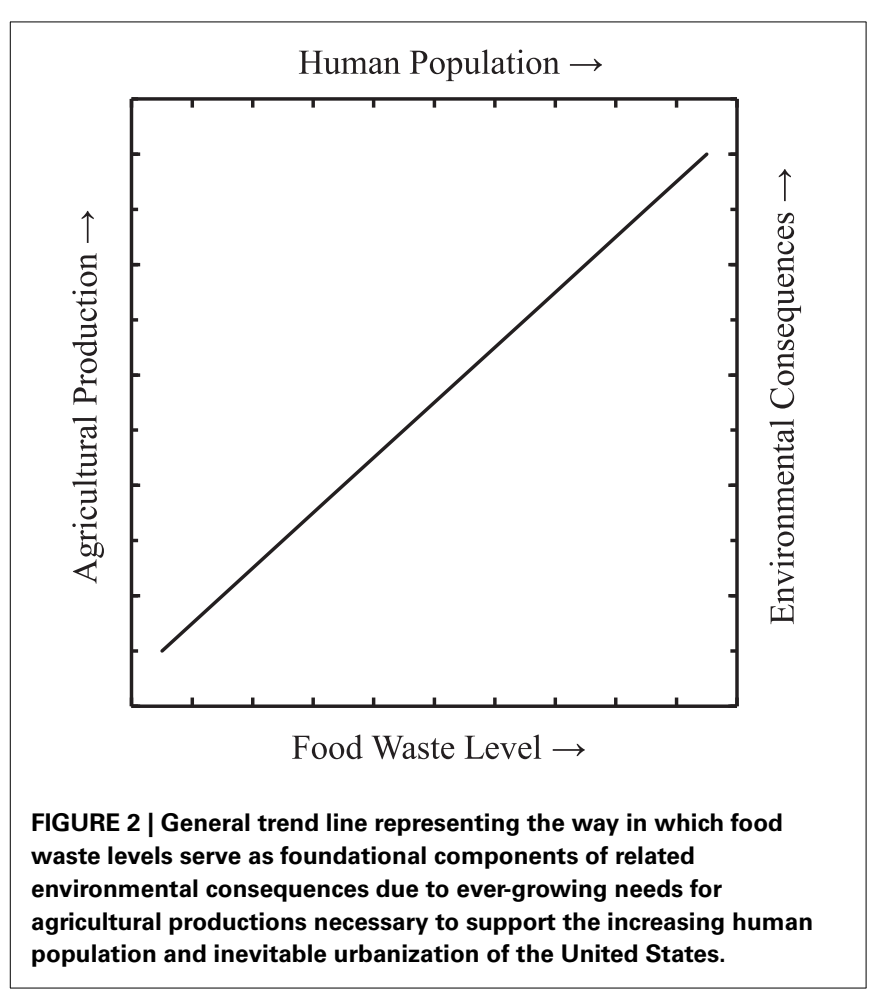

and there will be no viable option for agricultural support of such populations other than declaration of emergency preservedwildlife-reserve-use for farmland purposes. Looking at the bigger picture, wildlife species bear the burden against near-future food crises and the essential key to avoid tragedy while maintaining an environmentally diverse and sustainable earth is control of food waste.

\section{CONCLUSION}

As with most human-induced environmental instability factors, the causal influence of environmental degradation is greed of personal gain. From perspectives of legislation, commercial agribusiness, and consumers, practices of environmental carelessness concerning food waste result in economic control, excess profits, and nutritional indulgence, respectively. As a result of such selfishness on a national scale in the United States, little hope remains as all available evidence collectively suggests that sufficient change will not be exhibited prior to mass famine or financial catastrophe due to immense disorganization at the federal, commercial, and consumer levels. If food waste levels were diminished in the United States, growing populations could be sustained using current agricultural geographies with a lesser need for immediate and continuous expansion of farmland or impact on neighboring nations; an overall practice that additionally sustains earth's wildlife and resources. Instead, the United State's citizens will waste food at levels that cannot sustain the growing population and will be forced to drain neighboring nations of agricultural resources to maintain a viable economy resulting in mass food shortages in underpowered regions and distorted world order. Food waste levels in the United States serve as the key to the sustainability of earth's resources of tomorrow.

\section{ACKNOWLEDGMENTS}

This article was prepared as a result of USDA-NIFA CBG Student Learning and Teaching Program Effort. Additional funding for the classroom teaching and student research was provided from NSF-EPSCOR DSU CIBER Program. A special word of thanks is due to Dr. Jung-Lim Lee for his valuable and encouraging insight concerning the content discussed in this document and also being a wonderful research mentor to the first author, $\mathrm{Mr}$. Hickey during his studies in Delaware State University.

\section{REFERENCES}

Agricultural Act. (2014). "H. R. 2642," in 113th United States Congress. Washington, DC.

Alfaro, B., and Hernandez, I. (2013). Evolution of the indigenous microbiota in modified atmosphere packaged Atlantic horse mackerel (Trachurus trachurus) identified by conventional and molecular methods. Int. J. Food Microbiol. 167, 117-123. doi: 10.1016/j.ijfoodmicro.2013.08.017

American Farmland Trust. (2007). Threatened Farmland: What's Happening To Our Farmland? Available online at: http://www.farmland.org/resources/fote/

Arvanitoyannis, I. S., Kotsanopoulos, K. V., and Veikou, A. (2014). Life Cycle Assessment (ISO 14040) implementation in foods of animal and plant origin: review. Crit. Rev. Food Sci. Nutr. 54, 1253-1282. doi: 10.1080/ 10408398.2011.631170

Becchetti, C., and Neri, A. (2013). Medical Instrument Design and Development: From Requirements to Market Placements. Noida: John Wiley \& Sons, 475-476.

Botkin, D. B., and Keller, E. A. (2011). Environmental Science: Earth as a Living Planet. Wiley-Interscience, New York, 8th Edn. Hoboken, NJ: John Wiley \& Sons.

Boxstael, S. V., Devlieghere, F., Berkvens, D., Vermeulen, A., and Uyttendaele, M. (2014). Understanding and attitude regarding the shelf life labels and dates on pre-packed food products by Belgian consumers. Food Control 37, 85-92. doi: 10.1016/j.foodcont.2013.08.043

Buckley, P., and Carney, C. (2013). The potential to reduce the risk of diffuse pollution from agriculture while improving economic performance at farm level. Environ. Sci. Policy 25, 118-126. doi: 10.1016/j.envsci.2012. 10.002

Buzby, J. C., and Hyman, J. (2012). Total and per capita value of food loss in the United States. Food Policy 37, 561-570. doi: 10.1016/j.foodpol.2012.06.002

Buzby, J. C., Hyman, J., Stewart, H., and Wells, H. F. (2011). The value of retail- and consumer-level fruit and vegetable losses in the United States. J. Consum. Affairs 45, 492-515. doi: 10.1111/j.1745-6606.2011.01214.x

Cabello, F. C. (2006). Heavy use of prophylactic antibiotics in aquaculture: a growing problem for human and animal health and for the environment. Environ. Microbiol. 8, 1137-1144. doi: 10.1111/j.1462-2920.2006.01054.x

Datta, P. K. (2014). Agricultural sustainability and economic development: a cross - country analysis. Merit Res. J. Agric. Sci. Soil Sci. 2, 7-23.

Deibel, E. (2013). Open variety rights: rethinking the commodification of plants. J. Agrarian Change 13, 282-309. doi: 10.1111/joac.12004

Environmental Protection Agency (EPA). (2012). Water Polluted Runoff: What is Non-Point Source Pollution? Available online at: http://water.epa.gov/polwaste/ nps/whatis.cfm

Environmental Protection Agency (EPA). (2014). The Food Recovery Challenge. Food Waste Hierarchy. Available online at: http://www.epa.gov/ foodrecoverychallenge/

Finkbeiner, M., Inaba, A., Tan, R. B. H., Christiansen, K., and Kluppel, H. J. (2006). The new international standards for Life Cycle Assessment: ISO 14040 and ISO 14044. Int. J. Life Cycle Assess. 11, 80-85. doi: 10.1065/lca2006.02.002

Food and Agricultural Organization of the United Nations (FAO). (2009). How to Feed the World 2050. High-Level Expert Forum. Global agriculture towards 2050. Technology Challenge. Office of the Director, Agricultural Development Economics Division Economic and Social Development Department Viale delle Terme di Caracalla, 00153 Rome, ITALY. Available online at: http://www.fao.org/filead $\mathrm{min} /$ templates/wsfs/docs/Issues_papers/HLEF2050_Technology.pdf

Food and Agricultural Organization of the United Nations (FAO). (2013). The State of Food and Agriculture: Investing In Agriculture for a Better Future, (Rome). Available online at: http://www.fao.org/docrep/018/i3300e/i3300e.pdf 
Food and Agricultural Organization of the United Nations (FAO). (2012). Food Consumption. Available online at: www.fao.org/fileadmin/templates/ ess/documents/food_security_statistics/FoodConsumptionNutrients_en.xls

Giusti, I. (2009). A review of waste management practices and their impact on human health. Waste Manag. 29, 2227-2239. doi: 10.1016/j.wasman.2009. 03.028

Grassley, C. (2014). "Congressional Record," in Proceedings and Debates of the 113th Congress, 2nd Session, Vol. 160 (Washington, DC), S645-S646.

Gunders, D. (2012). Wasted: How America is Losing up to 40 Percent of its Food from Farm to Fork to Landfill. New York, NY: The Natural Resources Defense Council (NRDC).

Gustavsson, J., Cederberg, C., Sonesson, U., van Otterdijk, R., and Meybeck, A. (2011). Global Food Losses and Food Waste: Extent, Causes and Prevention. Rome: FAO.

Hall, K. D., Guo, J., Dore, M., and Chow, C. C. (2009). The progressive increase of food waste in America and its environmental impact. PLOS ONE 4:e7940. doi: 10.1371/journal.pone.0007940

Hanson, S. P. (2011). United States Patent Number: 7,963,469 B2. Washington, DC: U.S. Patent and Trademark Office.

Kalam, M. A., Masjuki, H. H., Jayed, M. H., and Liaquat, A. M. (2011). Emission and performance characteristics of an indirect ignition diesel engine fuelled with waste cooking oil. Energy 36, 397-402. doi: 10.1016/j.energy.2010.10.026

Kantor, L. S., Lipton, K., Manchester, A., and Oliviera, V. (1997). Estimating and addressing America's food losses. Food Rev. 20, 2-12.

Kersebaum, K. C., Steidl, J., Bauer, O., and Pior, H. P. (2003). Modeling scenarios to assess the effects of different agricultural management and land use options to reduce diffuse nitrogen pollution into the river Elbe. Phys. Chem. Earth 28, 537-545. doi: 10.1016/S1474-7065(03)00090-1

Koroneos, C., Roumbas, G., Gabari, Z., Papagiannidou, E., and Moussiopoulos, N. (2005). Life Cycle Assessment of beer production in Greece. J. Clean. Prod. 13, 433-439. doi: 10.1016/j.jclepro.2003.09.010

Kagabo, D. M., Stroosnijder, L., Visser, S. M., and Moore, D. (2013). Soil erosion, soil fertility and crop yield on slow-forming terraces in the highlands of Buberuka, Rwanda. Soil Tillage Res. 128, 23-29. doi: 10.1016/j.still.2012.11.002

Kuswandi, B., Anggi Restyana, J., Abdullah, A., Yook Hang, L., and Ahmad, M. (2012). A novel colorimetric food package label for fish spoilage based on polyaniline film. Food Control 25, 184-189. doi: 10.1016/j.foodcont.2011.10.008

Macé, S., Cornet, J., Chevalier, F., Cardinal, M., Pile, M. F., Dousset, X., et al. (2012). Characterisation of the spoilage microbiota in raw salmon (Salmo salar) steaks stored under vacuum or modified atmosphere packaging combining conventional methods and PCR-TTGE. Food Microbiol. 30, 164-172. doi: 10.1016/j.fm.2011.10.013

Mardsen, T., and Morley, A. (2014). Sustainable Food Systems: Building a New Paradigm. London; Routledge, NY: Taylor \& Francis.

Mensitieri, G., Di Maio, E., Buonocore, G. G., Nedi, I., Oliviero, M., Sansone, L., et al. (2011). Processing and shelf life issues of selected food packaging materials and structures from renewable resources. Trends Food Sci. Technol. 22, 72-80. doi: 10.1016/j.tifs.2010.10.001

Nellemann, C. (2009). The Environmental Food Crisis: The Environment's Role in Averting Future Food Crises. United Nations Environmental Protection (UNEP). Birkeland: Birkeland Trykkeri AS. 23-30.

New Zealand Biodiversity, (NZB). (2013). Biodiversity in New Zealand, Current state: Habitat destruction. Available online at: https://www.biodiversity.govt.nz/ picture/biodiversity/state/destruction.html

Payne-Palacio, J., and Theis, M. (2011). Foodservice Management: Principles and Practices. Prentice Hall, New Jersey, 12th Edn. Upper Saddle River, NJ: Prentice Hall.

Reimer, A., and Prokopy, L. (2014). One federal policy, four different policy contexts: an examination of agri-environmental policy implementation in the Midwestern United States. Land Use Policy 38, 605-613. doi: 10.1016/j.landusepol.2014.01.008

Saer, A., Lansing, S., Davitt, N. H., and Graves, R. E. (2013). Life cycle assessment of a food waste composting system: environmental impact hotspots. J. Clean. Prod. 52, 234-244. doi: 10.1016/j.jclepro.2013.03.022

Schwab, J. (2010). Environmental Protection Agency (EPA), Office of Solid Waste and Emergency Response (OSWER). Washington, DC: Personal interview with J. Buzby.

Stuart, T. (2009). Waste: Uncovering the Global Food Scandal. London, UK: Penguin W. W. Norton \& Company, Inc., NY.

Sundberg, C., Yu, D., Frank-Whittle, I., Kauppi, S., Smars, S., Insam, H., et al. (2013). Effects of $\mathrm{pH}$ and microbial composition on odour in food waste composting. Waste Manage. 33, 204-211. doi: 10.1016/j.wasman.2012.09.017

Takata, M., Fukushima, K., Kino-Kimata, N., Nagao, N., Niwa, C., and Toda, T. (2012). The effects of recycling loops in food waste management in Japan: based on the environmental and economic evaluation of food recycling. Sci. Total Environ. 432, 309-317. doi: 10.1016/j.scitotenv.2012.05.049

Themelis, N. J., and Ulloa, P. A. (2007). Methane generation in landfills. Renew. Energ. 32, 1243-1257. doi: 10.1016/j.renene.2006.04.020

United States Census Bureau. (2014). International Programs: Population by Nation, United States Department of Commerce. Available online at: http://www.census. gov/population/international/data/countryrank/rank.php

van der Horst, K., Brunner, T. A., and Siegrist, M. (2010). Ready-meal consumption: associations with weight status and cooking skills. Public Health Nutrit. 14, 239-245. doi: 10.1017/S1368980010002624

Volk, M., Liersch, S., and Schmidt, G. (2009). Towards the implementation of the European Water Framework Directive? Lessons learned from water quality simulations in an agricultural watershed. Land Use Policy 26, 580-588. doi: 10.1016/j.landusepol.2008.08.005

Warner, M. (2013). Pandora's Lunchbox: How Processed Food Took Over the American Meal. San Jose, CA: Simon \& Schuster. Scribner. Simon and Schuster Digital Sales Inc. NY, USA.

Weber, E. U., and Stern, P. C. (2011). Public understanding of climate change in the United States. Am. Psychol. 66, 315-328. doi: 10.1037/a0023253

Weidema, B. (2014). Has ISO 14040/44 failed its role as a standard for Life Cycle Assessment? J. Ind. Ecol. 18, 324-326. doi: 10.1111/jiec.12139

World Animal Foundation, (WAF). (2013). Habitat Destruction. Available online at: http://www.worldanimalfoundation.net/f/HabitatDestruction.pdf

Yan, S., Li, J., Chen, X., Wu, J., Wang, P., Ye, J., et al. (2011). Enzymatical hydrolysis of food waste and ethanol production from the hydrolysate. Renew. Energy 36, 1259-1265. doi: 10.1016/j.renene.2010.08.020

Conflict of Interest Statement: The authors declare that the research was conducted in the absence of any commercial or financial relationships that could be construed as a potential conflict of interest.

Received: 30 September 2014; accepted: 08 November 2014; published online: 28 November 2014.

Citation: Hickey ME and Ozbay G (2014) Food waste in the United States: A contributing factor toward environmental instability. Front. Environ. Sci. 2:51. doi: $10.3389 /$ fenvs.2014.00051

This article was submitted to Environmental Health, a section of the journal Frontiers in Environmental Science.

Copyright (C) 2014 Hickey and Ozbay. This is an open-access article distributed under the terms of the Creative Commons Attribution License (CC BY). The use, distribution or reproduction in other forums is permitted, provided the original author(s) or licensor are credited and that the original publication in this journal is cited, in accordance with accepted academic practice. No use, distribution or reproduction is permitted which does not comply with these terms. 